\title{
The Background of Zeami's Treatises
}

\author{
by J. Thomas Rimer
}

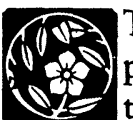

The $n \bar{o}$ theater of Japan, one of the most remarkable performing traditions in world theater, was brought to its first and highest flowering by Zeami Motokiyo (1363-1443). Zeami, building on the insights and experiences of his father Kan'ami, was able through his own skills and abilities to transform what had been essentially a country entertainment with strong ritual overtones into a superb total theatrical experience in which mime, dance, poetry, and song were combined so that each art could be transcended in order to produce for his audiences an experience of profundity and almost religious exhilaration.

Zeami's treatises, in which he discusses the principles of his art, remain unique documents in the history of the $n \bar{o}$. They stand as crucial statements that can inform a modern reader, just as they were meant to inform Zeami's professional colleagues, of the essential elements in the theatrical process as Zeami understood them. From our twentieth-century point of view, the treatises seem to serve two widely differing functions. On the one hand, Zeami's notions of the interlocking functions of acting, music, and movement in the $n \bar{o}$ reveal a remarkably contemporary consciousness. Despite the poetic and often arcane language Zeami uses, a performer can still find much here that seems altogether appropriate to the craft of acting. My colleague, Mr. Yamazaki concentrates on this aspect of the treatises in his essay. On the other hand, the treatises tell us an enormous amount about the early development of the $n \bar{o}$, a form of theater profoundly grounded in the specifics of medieval Japanese culture. My purpose here is to suggest enough of the historical background to provide a useful context for an understanding of Zeami's concerns. 


\section{xviii | J. Thomas Rimer}

Considering the stature of Zeami, a celebrity during his own lifetime, it seems remarkable that we know so little about him. ${ }^{1} \mathrm{He}$ was a child performer in the troupe of his father Kan'ami (1333-1384). When he was a boy of twelve, his remarkable talents were first noticed by the Shoggun Ashikaga Yoshimitsu (1358-1408), as powerful a patron of the arts as he was a political figure. Zeami's beauty both as a boy and as a performer attracted Yoshimitsu's patronage, as well as the encouragement and support of Nijō Yoshimoto (13201388), a leading renga poet of the time. Zeami's intellectual and artistic training was surely encouraged by such men in the court as these, for it is clear from the treatises that Zeami was a man well-versed in the details of literature, poetry, and philosophy. Normally, such matters would have been little known to an actor, since the social status of performers at this period was low indeed.

Zeami's father died when the young actor was only twentytwo, leaving him with the considerable responsibility of carrying on the tradition of his family troupe. Indeed, Zeami's stated purpose in writing his first treatise, Teachings on Style and the Flower, was to record the experiences of his gifted father and to comment on his own observations as a performer who attempted to follow in that tradition.

Zeami and his troupe evidently enjoyed the continuing patronage of Yoshimitsu until his death in 1408, but the Ashikaga successor, Yoshimitsu's eldest son Yoshimochi (13861428) seems to have favored another actor Zōami, a gifted performer in a rival dengaku troupe. Zeami admired Zōami and others of his contemporaries as well, and he learned from them, as the treatises make clear.

${ }^{1}$ For a judicious and detailed treatment of Zeami's life, see Thomas Hare's introduction in his dissertation (not yet published), "Zeami's Style: A Study of the 'mugen' Noh Plays of Zeami Motokiyo," University of Michigan, 1981. Yamazaki Masakazu's 1963 play Zeami is an attempt to dramatize many of those same facts. A translation is available in the volume Mask and Sword: Two Plays for the Contemporary Japanese Theatre by Yamazaki Masakazu (New York: Columbia University Press, 1980). 
Yoshimochi may have been indifferent to Zeami, but after the Shögun's death in 1428, when Zeami was sixty-six, Yoshimochi's younger brother Yoshinori (1394-1441) took over the reigns of government. From this time on, Zeami and his family suffered real personal difficulties. In 1434, when Zeami was seventy-two, he was banished to the island of Sado, a remote area near Niigata, in th€ Japan Sea. Four years before, Zeami's second son Motoyoshi (who wrote down the text of Zeami's Reflections on Art) abandoned the acting profession and became a Buddhist priest. In 1432, Zeami's older son Motomasa died, and there is some suggestion that he was murdered. On'ami (1398-1467), a nephew of Zeami, was officially appointed head of Zeami's family troupe by the Shōgunate when Motomasa died. The reasons for these terrible events have never been made clear, but it may have been Zeami's opposition to On'ami, whom he considered an inferior artist, that caused his exile, and indeed Zeami did insist on passing his treatises on to his gifted son-in-law Komparu Zenchiku (1405-1468), refusing to give them to On'ami. Zenchiku himself became a playwright and a theoretician of the $n \bar{o}$ second in importance only to Zeami himself.

Yoshinori was assassinated in 1441. Tradition has it that Zeami was pardoned and allowed to return to the mainland before his death in 1443. Few details concerning the end of his life are known, however, and inference and speculation often account for many important details of his career. In terms of Zeami's artistic and intellectual attitudes, however, the treatises do tell us much about his convictions and enthusiasms. In that way, at least, the spirit of this remarkable artist can be known to us.

Zeami, of course, never imagined that the works translated in this volume would ever be widely read. They were originally intended for a small circle of intimates and were written for the purpose of passing on matters of professional concern from one generation to the next. Zeami's troupe, like the others performing at his time, was organized on an hereditary 
basis, and these treatises were written for those already initiated into the art.

The idea of writing such secret treatises did not originate with Zeami. Such documents have always been important in Japanese culture, first perhaps in the esoteric sects of Buddhism, then in the realm of court poetry composition, where secret traditions for the writing of waka and renga were passed on through successive generations of the great court families, who jealously guarded their private treatises on the secrets of excellence in poetic composition. ${ }^{2}$ As far as modern scholarship has been able to ascertain, however, no such elaborate treatises on the art of the $n \bar{o}$ were written before Zeami's time. Perhaps Zeami's early training in poetry through his contacts with Yoshimoto and Yoshimitsu helped suggest to him the idea of composing such documents, and indeed the very existence of such treatises would doubtless help to dignify a profession that had heretofore seemed of little social account. In order to insure continued patronage, Zeami must surely have felt it necessary to consolidate what he learned from his father and to do all that he could to insure that his descendants might be as successful as possible, financially and artistically, in their endeavors. It is clear, however, from various remarks in the treatises, that these documents contained information that was not to be shared with other actors outside the family, or with the public, in any form. The secrets of the art were to be passed on privately, and the treatises shown only to those who were properly initiated.

For that reason, the texts of these works were not available to the Japanese public until the twentieth century. After Zeami's time, the $n \bar{o}$ continued as a theatrical form of great popularity, and by the seventeenth century, in the early Tokugawa period, the development of printing and the interest shown by a growing number of amateurs in the no gave rise

${ }^{2}$ See various entries in Brower and Miner, Japanese Court Poetry, for the development and transmission of poetic treatises. There is also a useful article on the subject of Komiya Toyotaka, "Nō to hiden," in Nogami Toyoichirō, ed., Nögaku zensho (Tokyo: Sōgensha, 1942-1944), I, 275-315. 
to the publication of certain play texts and a much bowdlerized version of portions of Teachings on Style and the Flower. The authentic texts by Zeami, however, remained in private hands until 1908, when a collection of the genuine treatises was discovered in a Tokyo secondhand bookstore. Purchased by a wealthy collector, they were edited by the writer Yoshida Togo and published in 1909 under the auspices of the Society for the Study of Nö Literature. These texts were collated with other versions that came to light, and the first set of definitive texts were published in the 1940 s by a leading scholar of the $n \bar{o}$, Nose Asaji, in his two-volume Zeami jüroku bushū (The Sixteen Treatises of Zeami). Since the war, another generation of meticulous Japanese scholarship has produced the now standard editions used in the preparation of these present translations. Certain pieces of information are missing, and some passages remain obscure, but we now have a fuller view of the critical writing of Zeami than would ever have been thought possible a few generations ago.

The range of the nine treatises included in the present volume is sufficiently wide that the reader can observe the changes in Zeami's own experience, from the early Teachings on Style and the Flower, in which he chronicles what he has learned from his father, to An Account of Zeami's Reflections on Art, taken down by his son Motoyoshi in 1430. A close study of the texts can show how Zeami's concepts developed as he gained experience. In the later treatises there seems an increasing predilection for searching out metaphysical explanations, often Buddhist in tone, for the kinds of practical insights that Zeami had learned both as a writer and as a performer. And, indeed, the treatises read more clearly and are more comprehensible as a whole than when read singly. Much that is unstated in one context is explained in another. Zeami conceived of the Way of the $n \bar{o}$, as he sometimes put it, in a manner similar to that of the Way of the waka poet or the Buddhist adept. The Way (michi in Japanese) suggests commitment, constant practice, and a genuine humility on the part of the one who is sincere in seeking a true path toward 


\section{xxii | J. Thomas Rimer}

enlightenment or excellence. ${ }^{3}$ It is not by accident that the word Path or Way occurs in the titles of several of Zeami's treatises, and it is the concept that ties all of them together.

For all the importance that Zeami places on the need for an inner concentration leading to a fixed goal, a modern reader will be struck again and again by Zeami's fascination with the freedom of the process involved. Nō may have grown out of ritual and folk art, but Zeami brought to such traditional assumptions an opportunity for a new and profound originality through his commitment to pleasing his audience, a process that required a judicious use of the traditional and the unexpected. In this sense, the treatises show an almost revolutionary spirit at work. Zeami was willing to set aside canons of traditional taste when the occasion demanded it. In this regard, he goes beyond his mentors in the field of waka and renga.

The important aesthetic concepts developed by Zeami in the course of these treatises could well form the basis for an extended study. In any case, he explains his ideas in such striking and poetic language that no lengthy preface is required here. At the least, however, it might be well to mention here several key terms as a signal to the reader that these conceptswhich usually become more clear when all the treatises are read-are crucial to Zeami's central patterns of thought.

One is that of the Flower (hana), a symbol used by Zeami for the true beauty created by the actor's performances in different ways throughout his career. By the use of this natural symbol, Zeami maintains a deep connection between the forces and movements of nature and the work of the committed actor, who in his art must attempt to recreate and symbolize those patterns and relationships. Then too, as Arthur Waley first suggested in his 1921 volume The No Plays of Japan, the idea of mystic transmission is involved in the concept of the Flower. The alternate title of the Füshikaden (which we have

${ }^{3}$ See Brower and Miner, Japanese Court Poetry, p. 257. For a full discussion of the concept of michi in medieval Japanese aesthetics, see Konishi Jin'ichi, Michi-chūsei no rinen (Tokyo: Kōdansha, 1975). 
rendered as Teachings on Style and the Flower) is the Kadensho, which might be literally translated as "The Book for the Transmission of the Flower," perhaps a reference to the mysterious transfer of thought from the Buddha to his disciple Kāśyapa, an incident mentioned in the treatises by Zeami himself. It is doubtless for this reason that Zeami often observes in the course of the treatises that some particular point cannot be explained in words alone but requires an intuitive understanding on the part of the actor.

Another concept crucial to Zeami's thought is that of a fundamental rhythm basic to the $n \bar{o}$, and, as he points out on several occasions, to all of nature itself. Zeami categorizes this basic rhythmical movement as jo (introduction), ha (breaking), and $k y \bar{u}$ (rapid), a gradual increase of pace from slow to fast. Scholars have identified various sources for this concept that go back as far as the patternings for the bugaku dances imported into Japan from China in the Heian period (794-1185). Zeami, however, seems to have been the first to use such a rhythmic pattern as a metaphor for the deepest psychological movement inherent in a successful theatrical experience.

Another powerful idea in Zeami's treatises concerns the relationship of $y \bar{u} g e n$, which we have translated as Grace, with the concept of monomane, sometimes translated as imitation but rendered in our translation by the term Role Playing so as to avoid too strict a suggestion of Western mimesis. A number of the most striking passages in the treatises deal with a need to create in the spectators a sense of the beauty that lies behind and beyond the kind of surface portrayal possible through the creation by the actor of any mere outward verisimilitude of the character being portrayed.

In addition to Zeami's own concepts, these treatises also provide for the student of comparative theater history or of Japanese medieval culture an enormous amount of fascinating specific information, often presented in a vivid fashion, of artistic life during Zeami's lifetime. Although it is true that methods of performing the $n \bar{o}$ established at that period still 


\section{xxiv | J. Thomas Rimer}

continue, the kind of stately experience usually offered today seems at some variance with the rough-and-tumble world described in the treatises. Zeami's milieu involved constant competition, and he always remained anxious to make his troupe successful and to keep it so. He has praise for others, but he shows himself as well an astute critic of performers from rival groups; and, indeed, his comments are so shrewd that, although the particulars of the acting styles are no longer always clear to us, the general import of his remarks always remains precise and vivid.

Four of the major troupes that perform today can trace their lineage back to the time of Zeami (see chart 1). The fifth troupe now performing, usually referred to as the Kita school, was formed in 1618 by a gifted amateur actor, Shichiday $\bar{u}$ (1586-1653), who received special patronage from the allpowerful Tokugawa family. From this time on, official support for the $n \bar{o}$ from the Tokugawa Shoguns helped remove this form of drama from the public scene and brought about as well a standardization, an increased emphasis on elegance, and a slower pace to performances. The nō that we witness today has been filtered through the Tokugawa process of gentrification, with both gains and losses.

One important change during the early Tokugawa period involved the establishment of fixed dimensions for the no stage. The treatises make clear, however, that actors during Zeami's lifetime were quite prepared to perform in a variety of playing spaces; indeed, one test of their skill as performers concerned their abilities to adjust their movements and vocal production to a variety of environments. Evidently there was no regularized playing space during Zeami's lifetime, or at least there is no information remaining that allows us to describe such a place with confidence. Figure 1 is a modern rendering of the kind of space used for performances in front of the Shōgun, and so might be considered as somewhat typical.

The treatises also reveal that the method by which the plays were chosen for performance was somewhat at variance with 


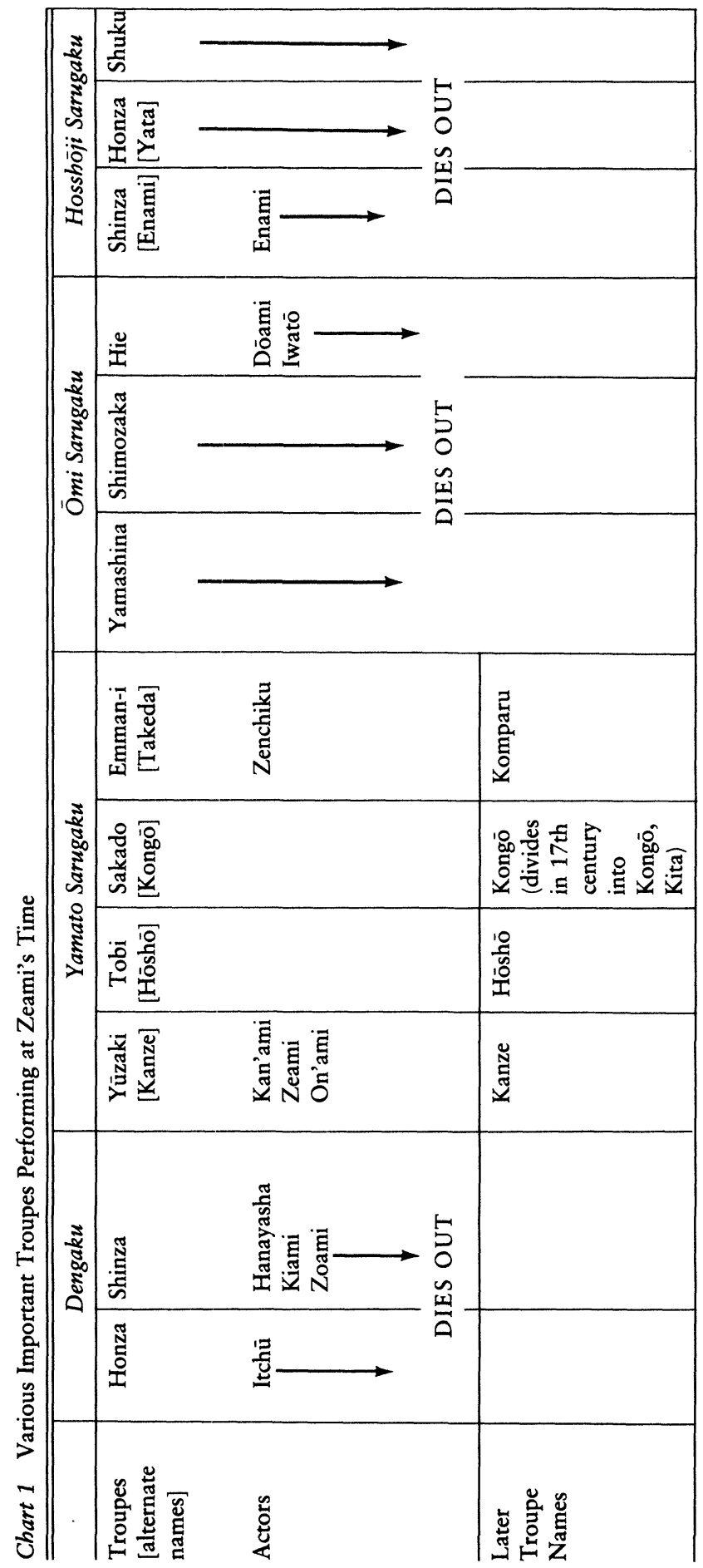


Figure 1. The Floorplan of a Performing Space Used at the Time of Zeami

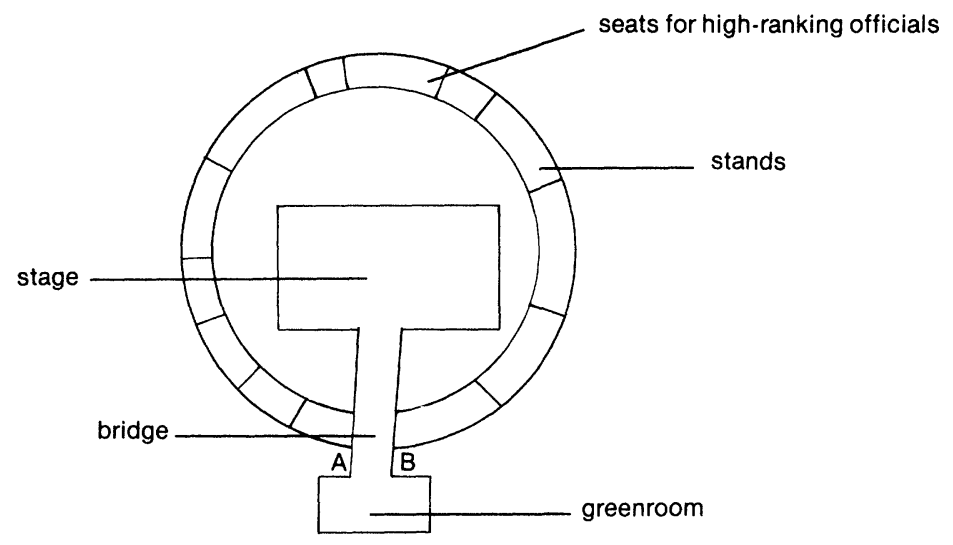

The Floorplan of a Modern Nō Stage

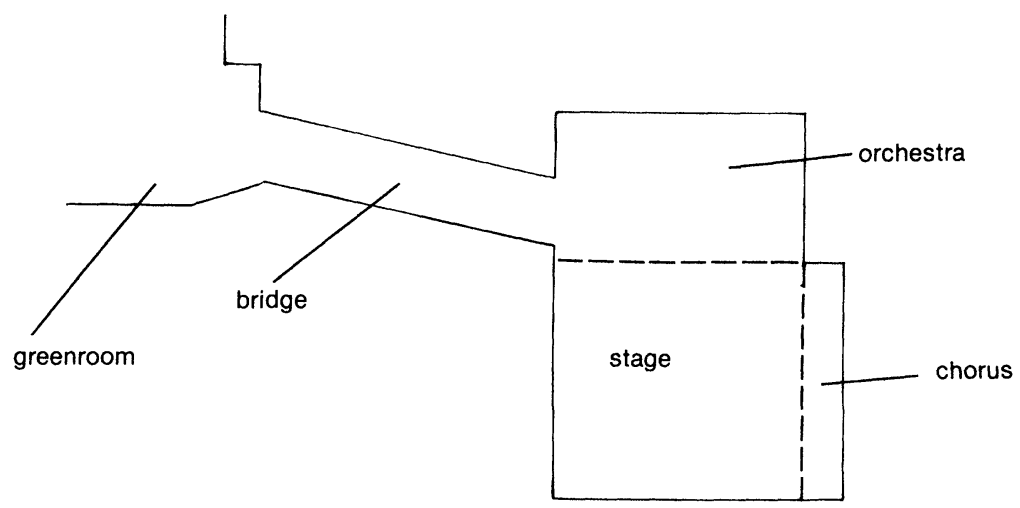

audience 
the modern method of selecting a $n \bar{o}$ program. There is no mention in any of the treatises of the so-called Five Groups or Five Categories by which the $n \bar{o}$ are catalogued today, a grouping into plays concerning (1) gods, (2) warriors, (3) women, (4) mad persons, and (5) demons. The pace in this scheme moves from slow to fast, category 1 being the most sedate, and category 5 the most wild and volatile. Such a schematization was evidently imposed later, probably during the Tokugawa period. ${ }^{4}$ Zeami's ideas were more flexible and less orthodox, in keeping with the importance he gave to the idea of novelty in his art.

A modern reader will notice at once that the repertory of $n \bar{o}$ pieces performed during Zeami's period was more varied and richer than what can be seen today. The modern repertory is chosen from a body of about two hundred fifty plays, yet a reading of Zeami's Reflections on Art shows that a number of important works performed at that time have not been retained in the repertory. Many of these plays still exist in manuscript, and some have been printed in large $n \bar{o}$ collections published in Japan early in this century. If all these texts could be located, a close reading of them and a collation of their themes would doubtless give us a very different, and a much more diverse, picture of the theater and of the mentality of Zeami's time.

Current scholarship indicates that there are in the present canon about fifty works that can fairly be attributed to Zeami. Some of these modern printed versions, however, are often simplified, even bowdlerized. In addition, there are sixteen or seventeen $n \bar{o}$ by Zeami that are not performed and for which texts are difficult to obtain. A few, of course, have been lost. Quite a few of Zeami's plays have been translated into Western languages, but, as Zeami's Reflections on Art makes clear, a number of those considered important during his lifetime

${ }^{4}$ Scholarly opinion differs as to how and when the various systems of classification for various types of nō came into being. For an extended discussion of the problem, see Kanai Kiyomitsu, Nō no kenky $\bar{u}$ (Tokyo: Ōfusha, 1969), pp. 152-179. 


\section{xxviii | J. Thomas Rimer}

remain quite unknown to modern Japanese or Western readers. Many of these submerged works deal with themes and figures from Shintō myth and legend, pointing to an aspect of ritual and belief that is much less visible in the better-known and often elegant plays based on Buddhist themes. The treatises suggest that the psychological attitudes of Zeami and his contemporaries, for all the affinities we may feel, show strong qualities that are foreign to a modern mentality, Japanese or Western. There remains something rich and strange about Zeami and his world. Working over the treatises, it has seemed to me that, whatever we gained in the centuries since his death, we have lost something as well-a quality perhaps best expressed in that awe Zeami felt before the processes of nature and art, an awe that for him was a necessary prelude to individual creation. If our translations can suggest in some fashion the importance of that awe to Zeami, and perhaps its potential value to us, then Mr. Yamazaki and I will be gratified indeed. 